\title{
El conflicto religioso en las escuelas rurales federales de Texcoco y Chalco, 1923-1933
}

\section{Religious Conflict in the Federal Rural Schools of Texcoco and Chalco, 1923-1933}

\author{
Juan B. Alfonseca Giner de los Ríos \\ Instituto Superior de Ciencias de la Educación del Estado de México \\ j_alfonseca@yahoo.es
}

\begin{abstract}
Resumen
En este escrito se analiza la historia de las escuelas rurales federales de la región de Texcoco y Chalco en los días del llamado Conflicto Religioso que vivió la sociedad mexicana durante los años 1926-1929, cuando el combate entre la ideología y la fe derivó en una nueva guerra civil. El registro y estudio de las manifestaciones del conflicto local de las escuelas condujo, por una parte, a una crítica a la periodización usualmente empleada para fecharlo, ya que la pugna política e ideológica se hizo presente en la región desde inicios de 1923 y no había concluido aún a finales de los años treinta. Por otra parte, el carácter de sus manifestaciones permitió contrastar la región de estudio con otras del país donde este asumió rasgos cruentos, situación que puede explicarse a partir de los profundos procesos de escisión faccional presentes en la mayoría de sus pueblos.
\end{abstract}

Palabras clave: escolarización federal; conflicto religioso; faccionalismo; periodización histórica; alianzas y resistencias sociales.

\section{Abstract}

This work analyzes the history of the Federal Rural Schools in the Texcoco and Chalco region during the era of the religious conflict Mexican society experienced during the period from 1926 to 1929 , when the struggle between ideology and faith led to another civil war. The registration and study of the manifestations of the local conflict in the schools led, on the one hand, to a criticism of the periodization usually employed to date it, since the political and ideological struggle emerged in the region in early 1923 and had not ended by the late 1930s. On the other hand, a study of these manifestations made it possible to contrast the region studied with others in the country where they were more violent. This can be explained by the profound factional split experienced in the majority of towns.

Key words: federal schooling; religious conflict; factionalism; historical periodization; social alliances and resistance.

Fecha de recepción: 27 de marzo de 2014 Fecha de aceptación: 29 de agosto de 2014 


\title{
El conflicto religioso en las escuelas rurales federales de Texcoco y Chalco, 1923-1933
}

\author{
Juan B. Alfonseca Giner de los Ríos
}

\section{INTRODUCCIÓN}

E ste escrito analiza el orden político cotidiano de las escuelas rurales federales de los distritos de Texcoco y Chalco en los días del llamado Conflicto Religioso (1926-1929) y persigue aportar tanto al campo de los estudios históricos sobre la relación Estado-Iglesia católica durante el periodo posrevolucionario como al de los estudios sobre los procesos de escolarización desarrollados en el país por la Secretaría de Educación Pública (SEP) a partir de 1921.

Aunque ha tendido a periodizárselo como un proceso que se desenvuelve entre 1926 y 1929 -en la dinámica de la escalada político militar desatada por las declaraciones del arzobispo Mora y del Río de inicios de 1926, la inmediata promulgación de la Ley Calles, la suspensión del culto, el estallido de la guerra Cristera y los acuerdos de cesación del conflicto de 1929-, el conflicto se inscribe en el largo aliento del proceso de secularización iniciado por el Estado nacional a raíz de la Constitución liberal de 1857, interrumpido luego durante el porfiriato y relanzado de modo más profundo por la Constitución de 1917 (Blancarte, 1993; Guerra, 2007; Meyer, 1993). En el largo plazo de ese proceso de secularización, el Conflicto Religioso de 1926-1929 representó sólo una coyuntura, atravesada por un pasado de estructuras de relación entre la Iglesia católica y el Estado nacional, y generadora de impactos que se proyectaron más allá de su finalización formal en 1929, tal como lo muestran varios estudios recientes (Meyer, 2008; Smith, 2004).

Al tiempo que hace suyas preocupaciones por la periodización histórica presentes en ambos campos de estudio, este escrito se propone documentar y analizar las repercusiones del llamado Conflicto Religioso en el orden de las escuelas rurales implantadas por la Secretaría de Educación Pública - principal encargada de ejecutar el control curricular a que aspiraba la Ley Calles-en los distritos de Texcoco y Chalco, en el oriente del Valle de México. En particular, interesa profundizar en líneas de análisis abiertas recientemente por Jean Meyer (2007), el gran historiador del movimiento cristero, 
respecto de las formas armadas y civiles que revistió la pugna entre la Iglesia católica y el Estado nacional durante los años veinte del siglo pasado. ${ }^{1}$

Este trabajo deriva de un escrito mayor donde argumento que la reconstrucción del nivel local en el estudio de los procesos de escolarización debe conducir a los historiadores de la educación del periodo posrevolucionario a la crítica de los criterios de periodización inspirados en los estudios políticos que ha solido asumir, acercándolos a la historia cultural y a la aprehensión de la escolarización federal posrevolucionaria desde la concepción braudeliana del tiempo histórico como flujo de determinaciones entre estructura y coyuntura (Alfonseca, 2011).

\section{LA LEY CALLES Y SU RECEPCIÓN EN LA REGIÓN DE TEXCOCO Y CHALCO}

Tenían ya tres años de establecidas algunas escuelas federales de Texcoco y Chalco, cuando la publicación de la Ley Calles en junio de 1926 vino a crear las condiciones definitivas para el estallido del Conflicto Religioso entre el gobierno federal y el Episcopado y la grey mexicana, al castigar la violación de los artículos constitucionales relativos al ámbito religioso. Como es conocido, en respuesta al ordenamiento, el Episcopado emitió la histórica pastoral decretando la suspensión del culto que tan hondamente conmovió a la sociedad civil mexicana, llevándola a una nueva guerra civil de tres años, que culminó con el modus vivendi concertado entre el presidente Emilio Portes Gil y los representantes del Episcopado en junio de 1929, restableciéndose el culto poco tiempo después (Loyo, 1999, pp. 245-253; Torres-Septién, 1997, pp. 105-117).

${ }^{1}$ En una rectificación intelectual, Meyer (2007) llama la atención sobre las formas no violentas ni armadas del Conflicto Religioso, señalando: "Ahora pido prestado [...] al historiador Martín Broszat la distinción entre Widerstand, la resistencia política, eventualmente armada, en el sentido de levantamiento, y Resistenz, concepto médico-biológico, en el sentido de defensa del organismo para conseguir la inmunidad, resistencia inmunitaria. Los cristeros practicaron la Widerstand, mientras que en Oaxaca y en otros seis o siete estados se recurrió a la Resistenz, con bastante éxito. La Resistenz no aparece mucho en mi cristiada ya vieja de más de 30 años por la sencilla razón de que yo estudiaba la lucha armada, Widerstand de los católicos mexicanos entre 1926 y 1929; por eso no aparecen los cinco estados del Norte y los cuatro del Sureste. Eso no significa que el Conflicto Religioso no haya afectado la periferia, tampoco que los católicos de esas regiones no hayan defendido su Iglesia y sus iglesias, sino que lo hicieron en forma de Resistenz, sin recurrir a la lucha armada que se dio con gran fuerza en el Altiplano, en el Bajío, en el Occidente" (pp. 5-7).

\section{()(1) $\$$}


Culminación de un trienio de pugna entre ambas fuerzas, la ley escalaba el combate de la fracción callista contra la hegemonía política y cultural de la Iglesia católica, ${ }^{2}$ poniendo en manos del gobierno nacional instrumentos jurídicos para contener su influjo. Molesto por las "declaraciones"3 del arzobispo José Mora y del Río en el sentido de que el Episcopado resistiría la limitación constitucional de sus libertades, el presidente Plutarco Elías Calles encargó a sus secretarios la inmediata codificación de los ordenamientos necesarios para la aplicación legal del estatuto constitucional. Así, el secretario de educación José M. Puig Casauranc emitió el 22 de febrero de 1926 un reglamento provisional de escuelas primarias particulares, fundado en el principio de que esas escuelas sólo podrían existir sujetas a la vigilancia de la Secretaría de Educación Pública. El reglamento normaba las cuatro primeras fracciones del artículo $3^{\circ}$ de la Constitución de 1917, que establecían la enseñanza laica y la prohibición a corporaciones y agentes religiosos de establecer o dirigir instituciones de enseñanza primaria (Mutolo, 2005).

Aunque las disposiciones del gobierno federal creaban ya bases legales para el control curricular, se mantenían todavía dentro del laicismo. Si bien excluían a las corporaciones eclesiásticas del control de procesos de enseñanza, exigiéndoles el retiro de apelativos, imágenes y ritos de los planteles cuya incorporación se autorizase, no eran aún, definitivamente, lo intrusivas que serían las que vendrían en 1934 con la reforma educativa socialista, que establecería ya un currículo basado en el conocimiento racional, crítico de la teodicea y del fanatismo. Se trataba apenas de controlar y excluir del currículo ciertos aspectos de las confesiones, no de tornarlo en contra de ellas. ${ }^{4}$

No obstante, la medida de suspensión del culto fue contundente y creó un hondo sentimiento de ofensa en los creyentes mexicanos, sobre todo en los de los campos, sumando el descontento campesino a las levas del ejército cristero y generando en las localidades un clima que, allí donde las condicio-

${ }^{2} \mathrm{Y}$ de las fracciones de la familia revolucionaria por las que esta se inclinaba, según piensa Valenzuela (1998), para quien los antecedentes de la cristiada no deben situarse en hechos como la expulsión del delegado apostólico en 1923 o los enfrentamientos con Mora y del Río de 1926, sino en los días de la campaña presidencial que enfrentó a Plutarco E. Calles con Ángel Flores.

3 "Declaraciones", entre comillas, por cuanto se urdió una trama para hacer ver como presentes declaraciones hechas por Mora y del Río a poco de promulgada la Constitución de 1917. Mario Ramírez Rancaño (2006) la explica amenamente en su historia sobre el patriarca Pérez y la Iglesia Católica Apostólica Mexicana.

${ }^{4}$ Loyo hace interesantes apuntes en torno al débil alcance de la reglamentación propuesta por Puig Casauranc (Loyo, 1999, pp. 247-250).

\section{()ㅜ(1) 3}


nes lo permitieron, adquirió rasgos de cruzada contra las agencias del Estado federal, cuyos agentes fueron por ello vejados, tundidos, expulsados y muertos. A la escuela y los maestros rurales -a la sazón, profundamente imbuidos de meros ideales de alfabetismo y modernización higiénica y productiva-, el descontento del vecindario "fanático" tendió a constituirlos en arquetípicos objetos de revancha. ${ }^{5}$

\section{El tejido social en Texcoco y Chalco}

Pronto hicieron eco los campos de Texcoco y Chalco de las resistencias desplegadas por el Episcopado, la Liga Nacional Defensora de la Libertad Religiosa (LNDLR) y las redes civiles de culto. Pronto hubo en la cabecera regional de Texcoco y en el pueblo chalca de San Gregorio Cuautzingo sendas delegaciones de la Liga, que sólo contaba con tres más en el resto del Estado de México, hecho que muestra la importancia del aparato católico en esta región.

Tal vez porque el tejido social era otro, el Conflicto Religioso en Texcoco y Chalco no presentó los rasgos cruentos que tuvo, por ejemplo, en contextos agrarios cristeros del occidente del país, donde a la par de la insurgencia militar se produjeron profundos procesos de ruptura del orden civil. Ni los tuvo entonces, ni los tendría durante la nueva escalada de agitación religiosa que llevó a sus campos la coyuntura cardenista, cuando la "segunda cristiada" convirtió nuevamente al medio rural nacional en escena de tragedia para cientos de maestros muertos, mutilados y expulsados en incidentes de ajusticiamiento popular atizados desde el púlpito.

No, nada como aquello se vio por Texcoco y Chalco. Aunque hubo cierto accionar de cuadrillas de cristeros armados, capitaneadas por antiguos zapatistas como Rafael Ramos, Jesús María Martínez y Manuel Reyes (activas en el área de las estribaciones del Ajusco, Chalco, Chalma y Tenancingo), nuestra región jamás tuvo una actividad militar como la que existió en el sur del estado, en los municipios de Ixtapan, Malinalco, Ocuilán, Tenancingo, Tejupilco, Tonatico y Valle de Bravo. Por su cercanía con la ciudad de México, la región era estratégicamente adversa a la emergencia de guerri-

${ }^{5}$ Entre pocos estudios más, el de Yankelevich (1997) sobre la educación socialista en el estado de Jalisco incurre en la descripción de la violencia desatada contra los maestros rurales durante la guerra Cristera.

\section{(ㅇ)(1) $\$$}


llas e, incluso, de amotinamientos "fanáticos" severos. Pronto, la guarnición federal lograba presentarse en el teatro de operaciones y sofocar el descontento, como sucedió con los alzamientos de 1927 en el corredor montañoso del Ajusco, en cuya disolución intervino, incluso, la Fuerza Aérea Federal (Olivera, 1987, pp. 155-159), o como sucedería en los también contados incidentes de convulsión pública violenta contra la escuela registrados durante el cardenismo, cuando resultó claro que maestros e inspectores eran capaces de movilizar el apoyo de la tropa federal en cuestión de horas.

Pero no sólo por militarmente accesible dejó de ser la región escenario de radicalismo religioso. Sus mismos pueblos (el común de ellos podría agregarse) se hallaban lo suficientemente divididos en asuntos de ideología, confesión y política, como para pensar que la repulsa religiosa al Estado federal era capaz de lograr el consenso requerido para llegar al amotinamiento sangriento. Pueblos manifiestamente escindidos en asuntos de socialidad pública traman las escenas escolares del conflicto, convirtiendo a la escuela federal en un asunto de correlación de fuerzas entre alineamientos faccionales. En otras palabras, en un segmento importante del centenar de pueblos que integran ambos distritos, la agencia escolar no se hallaba completamente sola.

Comentando el libro de Moisés González Navarro sobre los cristeros de Jalisco, Matthew Butler (2002) apunta ideas en torno a un modelo de correlaciones históricas entre el entorno sociocultural agrario y la recepción dada por el campesinado a la agitación religiosa promovida por la Liga, el Episcopado y las redes eclesiásticas y civiles del poder religioso. Este autor piensa que el débil compromiso campesino con la agitación religiosa manifiesto en la región sur-central de Jalisco tuvo posiblemente que ver con la estructura de las relaciones sociales agrarias y con la presencia allí de tradiciones socioculturales de comunalismo y disidencia religiosa. Butler (2002) cita aspectos presentes en la historia cultural de la zona de Ocotlán, Zapotlán y Tlaquepaque (como la existencia de demandas agrarias de carácter colectivo y tradiciones de librepensamiento -liberalismo anticlerical, protestantismo-) que sentaron las bases de un comportamiento social de compromiso moderado con la agitación religiosa, cuando no fue que de lealtad al Estado federal. Pueblos y comunidades indígenas interesadas en litigios agrarios con el sistema de haciendas, en conflicto con el orden sociocultural sancionado por estas y por sus instituciones internas (culto, entre otras), configuraron, en su opinión, procesos que dieron vida a posicionamientos proclives al gobierno federal, a diferencia de la zona de Los Altos, donde la exacerbación

\section{(이요 $\$$}


cristera arraigó en contextos de pequeños propietarios libres, culturalmente individualizados y dominados por la Iglesia. ${ }^{6}$

En más de un punto se acercan las tradiciones socioculturales que Butler (2002) destaca en el sur liberal de Jalisco con las presentadas en la región de Texcoco y Chalco. Por supuesto, también los creyentes del oriente del Valle de México se vieron conmovidos por la suspensión del culto y las medidas gubernamentales paralelas al control sacerdotal, regulación y custodia de los templos clausurados. Sobre todo en la zona de Texcoco, donde el tejido eclesiástico tuvo claro poder para movilizar el descontento, la grey católica mostró un ardiente rechazo al ataque a la fe de la política federal. Sin embargo, la movilización de los católicos no generó violencia desencadenada, no sólo por la certeza de que la fuerza armada intervendría con presteza, sino porque sus actos fueron regularmente enfrentados por facciones locales que se les opusieron, en alianza con los propósitos culturales del Estado. Escindidos entre "agraristas" y "fanáticos"; entre liberales y conservadores, protestantes y católicos, los pueblos de Chalco y Texcoco tuvieron una peculiar vivencia del Conflicto Religioso: más cercana a la resistencia civil en el marco de equilibrios entre fuerzas políticas que al autoritarismo desenfrenado, de cuño tanto cristero como agrarista.

\section{El boicot cultural a la escuela federal}

En realidad, desde los inicios mismos de la escolarización federal, en 1923, la Iglesia local dio muestras de ver con malos ojos el ingreso de las escuelas de la Secretaría de Educación Pública, existiendo reportes de maestros misioneros e inspectores que consignan el despliegue de un verdadero proceso de boicot cultural contra sus planteles, organizado por el clero. Pronto comenzaron los púlpitos a propalar temor, duda y animadversión hacia la escuela rural federal. ${ }^{7}$

${ }^{6}$ La "creciente división histórica entre el Jalisco 'liberal' del sur y el Jalisco de Los Altos en materia tanto cultural, religiosa y política como agraria sugiere que las distintas formas de interacción entre las estructuras agrarias y las culturas religiosas locales serán factores clave en la participación popular en la Cristiada y nos ayudarán, por consiguiente, a explicar por qué esta convulsión social dividió tan profundamente al pueblo jalisciense" (Butler, 2002, pp. 511-512).

7 Yankelevich (1997) también sitúa orígenes anteriores a la coyuntura callista a la oposición del clero a la política educativa federal, al señalar: "Todavía estaba vigente el programa

\section{(ㅇ)(1) $\$$}


En abril de 1923, a poco tiempo de establecidas las primeras Casas del Pueblo, el misionero encargado de la zona de Texcoco, Ricardo Sánchez, escribía lo siguiente a Enrique Corona, jefe del Departamento de Cultura Indígena:

Bien comprendo, Sr. Corona, que si comunicara oficialmente ciertas dificultades de carácter religioso-social con que he venido tropezando [...] podría desvirtuar el propósito conciliador del Dpto. de Cultura Indígena [...] El sólo anuncio de que ya contarían con escuelas los diferentes pueblos de mi zona fue suficiente para que los vecinos [...] se entusiasmaran [...] y me ofrecieran toda clase de auxilios [...] pero desgraciadamente las maléficas prédicas de algunos curas, hicieron cambiar por completo el ambiente favorable [...]. I así fue como un lunes los maestros que abrían sus escuelas vieron con asombro que a estas no llegaban los alumnos cuyos padres fueron a misa el domingo retropróximo [...] Pero donde más guerra me hacen es en esta cabecera [...] cuyo Presidente Municipal, (que es caballero de Colón) de acuerdo con el cura del lugar, no sólo opone innúmeras dificultades [...] sino que contribuye para que los comisarios de los pueblos circunvencinos me vean con cierta desconfianza. El propio [...] Presidente Municipal, presidió una ceremonia literario-religiosa, cuyo programa enseñé a Ud. en días pasados, en la que un cura Icaza, que previamente fue llamado del Distrito Federal, dijo un discurso en términos sumamente agresivos contra la Secretaría de Educación. ${ }^{8}$

Una prédica que recorriese los púlpitos del municipio de Texcoco con el tácito acuerdo de la autoridad municipal debía ser asunto de honda preocupación para el misionero Sánchez, por abarcar ese municipio buena parte del territorio social bajo su jurisdicción y hallarse en sus pueblos la mayor parte de las Casas del Pueblo que controlaba. Sin embargo, el boicot no se circunscribía sólo a Texcoco. Poco tiempo después, Sánchez describía en estos términos la situación escolar en el contiguo municipio de Atenco:

Fue en este lugar a principios de año donde mayor entusiasmo se manifestó por aprender; pero ciertos compromisos de la autoridad local con un cura,

vasconcelista en Jalisco cuando la reacción clerical comenzó a sabotear aquel primer esfuerzo [de la federación] regenerador de la educación tapatía" (p. 112).

${ }^{8}$ Ricardo Sánchez a Enrique Corona. Texcoco, 30 de abril de 1923. Fondo Departamento de Educación y Cultura Indígena. Exp. 706.5. Archivo Histórico de la Secretaría de Educación Pública (AHSEP), México.

\section{()(1) $\$$}


han restado éxito a nuestra labor, al grado de que dos escuelas de la jurisdicción de Atenco las he tenido que clausurar por atropellos a los profesores [...] no me desanimo: primero, por el entusiasmo aún latente en los vecinos [...] segundo, porque sé que las personas que fungirán como autoridades el año próximo son los más fervientes defensores de la instrucción popular. ${ }^{9}$

Estos hechos se producían días después de la expulsión de México de monseñor Ernesto Filippi, delegado apostólico vaticano, suceso que escaló el conflicto entre el gobierno federal y el Episcopado, y que hizo emerger -ya desde 1923- los rasgos que presentaría la movilización de los católicos a partir de la Ley Calles, en julio de 1926. De hecho, 1923 debe marcarse como el origen de la coyuntura religiosa para las escuelas federales, al menos en las de Texcoco, donde el boicot cultural continuaría dando intermitentes señales de vida bajo la lógica del ataque desde el púlpito, la desobediencia de la autoridad política local y la poca participación de la infancia en los planteles.

Sin embargo, desde principios de 1926 comenzó a perfilarse claramente en los pueblos la movilización religiosa contra la escuela rural federal. La inquietud por los sucesos que siguieron a las declaraciones del arzobispo Mora y del Río (control sacerdotal, reglamentación de la enseñanza particular y clausura de conventos) pronto hizo presa de la región y ya para mayo comenzaron a emerger cambios subrepticios en la actitud hacia los planteles federales de los pueblos texcocanos como San Luis Huexotla, Pentecostés, Santa Catarina y otros más. En ese mes, la situación en el distrito de Texcoco rozaba grados de peligro, según lo describía al jefe de la guarnición militar el inspector escolar federal, al solicitarle que sus subordinados no interfiriesen en el asunto de las armas portadas por los maestros, ya que estos trabajaban "en lugares apartados, en donde el beneficio de la seguridad no existe [...] en pueblos cuya dictadura sacerdotal es manifiesta y perpetuamente tienen que sostener una lucha con quienes hacen inauditos esfuerzos para impedir la acción de la Secretaría”. ${ }^{10}$ Para diciembre, por instrucciones del presidente Calles, el secretario de Educación Puig Casauranc telegrafió al general encargado de la plaza militar de Texcoco, Herrera Quijano, pidiéndole impartir garantías civiles a los maestros rurales acosados por el presidente municipal,

${ }^{9}$ Informe. Texcoco, julio de 1923. Fondo Departamento de Educación y Cultura Indígena. Exp. 706.5. AHSEP, México.

${ }^{10}$ Inspector Miguel A. Gómez a jefe guarnición de la plaza. Texcoco, 26 de mayo de 1926. Fondo Dirección de Educación Federal en el Estado de México. Caja 829, expediente sin clasificar. AHSEP, México.

\section{()(1) $\$$}


Juan de Dios Irizar, e indicando que el "señor presidente ordena consignación culpables y encárgale [...] si repítense atropellos envíe usted Presidente Municipal o Comisario o cualquier otro culpable consignados directamente Presidencia República para su castigo". ${ }^{11}$

Entre las primeras de Texcoco, la Casa del Pueblo de Huexotla (establecida en 1923) no había producido noticia mayor hasta la llegada, a inicios de 1926, del nuevo maestro federal que habían gestionado insistentemente ante la SEP los comisarios del lugar, interesados en restituirle al plantel el director que algún día había tenido. Entre el inicio de esas gestiones en 1925 y el arribo final del maestro en el mes de febrero (poco después de las declaraciones de Mora y del Río), un cambio fue patente en el ánimo de los comisarios, ya que comenzaron a negarle todo tipo de apoyo al maestro. Un año más tarde, en plena guerra Cristera, cuando había tomado ya la decisión de clausurar el plantel, el inspector federal escribía sobre los motivos que habían definido la clausura de la escuela rural federal:

Habiendo solicitado el profesor Delfino Gutiérrez, su traslado a otro lugar más hospitalario que el pueblo de Huexotla [...] en donde se le negó proporcionarle casa en donde vivir él y su familia [...] Habiéndose negado el pueblo á proporcionar la luz para la escuela nocturna, lo mismo que [...] a facilitar el producto de la siembra del terreno federal inmediato al templo para que con ese dinero se comprara una lámpara de gasolina y otras varias causas más $[\ldots]^{12}$

¿Qué cambió en el parecer de los habitantes de Huexotla (o, al menos, en el de sus autoridades civiles) que dieron esa recepción al maestro que tanto habían gestionado, abortando el plantel al año de refundado? ¿Eran los comisarios que lo recibieron los mismos que lo solicitaron? ¿Se debió ese cambio a la escalada política que siguió a las declaraciones de Mora y del Río?

Sin duda que la impronta del Conflicto Religioso se hallaba en el trasfondo, como lo creían, entre otros, los señores Porfirio García, Maximiliano Estrada y Luz Fermoso, quienes decían conocer los motivos del cambio de actitud del poder local hacia la escuela federal. Según le hacían saber al pre-

${ }^{11}$ Rafael Ramírez a inspector Miguel A. Gómez. México, D. F., 8 de diciembre de 1926. Fondo Departamento de Escuelas Rurales. Caja 10, exp. 29. AHSEP, México.

${ }_{12}$ M. Gómez, inspector federal a director federal de Educación. Informe. Texcoco, 8 de febrero de 1927. Fondo Departamento de Educación y Cultura Indígena. Caja 4, exp. 6498. AHSEP, México.

\section{(ㅇ)(1) $\$$}


sidente Plutarco Elías Calles los 36 firmantes de un escrito de protesta por la clausura de la escuela, la principal razón había sido:

la ninguna ayuda que prestan las autoridades últimamente nombradas [...] que son las refractarias a la instrucción del pueblo [...] al progreso e ilustración del campesino y quienes continuamente murmuran contra la digna actitud de nuestro gobierno [...] esta y no otra, es la actitud de nuestro actual primer Comisario, el señor José Sánchez quien aliado con los individuos que forman aquí la Liga Católica, ha puesto tantas cuantas dificultades ha podido a la Escuela Federal para que fuera clausurada y no se impartan las saludables y progresistas enseñanzas [...] [H]emos hecho cuanto está de nuestra parte por conseguir, del C. Presidente Municipal de Texcoco, el cambio de dichas autoridades; lo que no hemos logrado, a pesar de haberle presentado un escrito [...] firmado por 76 individuos, que forma la mayoría del campesino consciente de este lugar. ${ }^{13}$

Algo más activa en aquellos días, resulta claro que la Liga Católica contaba con el consenso mayoritario en Huexotla, pueblo de unos 600 habitantes, donde escasas 30 familias se mostraban interesadas en la permanencia del plantel federal. Más allá de esto, lo relevante es lo que esas incidencias nos reflejan sobre el orden local y los procesos de implantación escolar: pueblos escindidos en torno a la "peligrosidad" de la escuela federal; unos, en resistencia civil a su implantación, otros en alianza emergente con el actor federal mediante el apoyo a la escuela.

No era la labor cultural de la escuela rural federal la que motivaba la reacción católica. Lejos de hallarse involucrados en una campaña anticlerical, los planes de trabajo de muchos maestros federales revelan un orden de preocupaciones fundamentalmente vinculado con el alfabetismo, la ilustración y la modernización higienista y productiva de los campesinos. Sus informes sobre la vida escolar hablan básicamente de huertos, anexos pecuarios y artesanales; de pláticas agrícolas y exhortos al trabajo productivo. Nula evidencia de una labor de posicionamiento público de la escuela en la coyuntura por la que atravesaba el gobierno existe en el archivo escolar.

${ }^{13}$ Luz Fermoso, Porfirio García, Maximiliano Estrada y demás vecinos firmantes a presidente Plutarco Elías Calles. Huexotla, 12 de febrero de 1927. Fondo Departamento de Escuelas Rurales. Exp. 7/6495. Ahsep, México.

\section{(ㅇ)(1) $\$$}


Seguramente la reacción se vinculaba más con las inquietantes medidas tomadas a principios de año por el inspector federal, que, apelando a la Ley de Bienes Nacionales, había obtenido la entrega del ex convento de San Francisco, en Texcoco, para establecer en él una escuela primaria superior, creándose cierto revuelo social en la cabecera. ${ }^{14}$ Como en el resto de la república, al catolicismo le inquietaba el giro amenazante que comenzaba a tomar la aplicación del artículo 27 de la Constitución, particularmente de su fracción segunda, que negaba al clero el derecho de poseer bienes inmuebles, lo que hacía temer una creciente intervención federal en relación con ellos. ${ }^{15}$ De hecho, los temores de que el Estado federal profundizase la jurisdicción constitucional que tenía sobre templos y otros edificios eclesiásticos se confirmaron a poco de que el Episcopado suspendiese el culto, cuando a las presidencias municipales llegó el aviso de que, a partir del 31 de julio, todos los templos permanecerían cerrados, prohibiéndose que los sacerdotes oficiasen o habitasen en ellos. También se autorizaba a la autoridad municipal a dar uso de utilidad pública a los templos clausurados de su demarcación, previo aviso al Departamento de Gobernación del estado (Castro, 2003, p. 184).

\section{EL COMBATE FACCIONAL EN TORNO AL ESPACIO ECLESIÁSTICO}

La suspensión del culto creó en los pueblos de Texcoco y Chalco un clima de profundo enfrentamiento faccional. El cierre de los templos y su tránsito subrepticio a la condición de "bienes de la nación" los convirtió en objeto de interés sobre el que comenzaron a avanzar -en evidente contraposición con los leales al Episcopado- distintos actores locales, interesados en apropiarse de ellos para el establecimiento de espacios de interés público (y ocasio-

${ }^{14}$ Inspector Miguel A. Gómez a director de Educación Federal. Texcoco, 30 de junio de 1926. Fondo Dirección de Educación Federal en el Estado de México. Caja 829, expediente sin clasificar. AHSEP, México.

${ }^{15}$ Andrea Mutolo (2005) sintetiza lo que involucraba la aplicación de la fracción segunda: "Abolición del derecho de propiedad para la Iglesia [...] Todos los edificios de la Iglesia tenían que convertirse en propiedad del Estado, los edificios sustraídos a la Iglesia tenían que ser destinados exclusivamente a los servicios públicos [...] Todas las iglesias fueron declaradas propiedad de la nación [...] El gobierno federal podía determinar cuáles iglesias estaban destinadas al culto religioso y cuáles no" (p. 120).

\section{(ㅇ)(1) $\$$}


nalmente privado) ${ }_{1}^{16}$ o para instaurar en ellos un nuevo sentido eclesiástico, como ocurría en el relevante caso del faccionalismo cismático adherido a la Iglesia Católica Apostólica Mexicana, que floreció en muchos pueblos de la región durante este lapso. ${ }^{17}$

\section{Tomas de postura en favor del actor federal}

Como facción socialmente configurada, el agrarismo tomó generalmente una posición de apoyo al régimen de Calles. Redactado en el mismo pueblo de San Gregorio Cuautzingo (donde más tarde tendría la LNDLR su delegación), el manifiesto de la Liga Fraternal de Campesinos y Obreros del Distrito de Chalco que entregaba al presidente Calles el apoyo de sus 6000 presuntos coaligados en la lucha contra el "pulpo católico", constituye un ejemplo de importancia central. ${ }^{18}$ Fundando su apoyo a la política federal en ideas típicas del cristianismo anticlerical campesino, los agraristas del distrito de Chalco reforzarían, a partir de la suspensión de cultos y de los sucesos que condujeron a la guerra Cristera, su disposición militante a favor del Estado federal. En diciembre de ese año, por ejemplo, volverían a escribir al presidente para denunciar que en la pulquería llamada El Atorón del Diablo se celebraban reuniones de carácter sedicioso a las que asistían católicos del pueblo dirigidos por el cura Cruz M. Flores. En comunicación posterior remitían propaganda católica incautada en el rumbo de Ixtapaluca, reiterando sus denuncias sobre movilización católica en San Gregorio Cuautzingo. ${ }^{19}$

Como los agraristas de Cuautzingo (que años más tarde sellarían su alianza con la escuela federal al instalarse esta allí en 1932), otros núcleos de campesinos de la región tomaron posición a favor de Calles al iniciar el conflicto. De algunos pueblos del rumbo de Texcoco, como San Simón, escri-

${ }^{16}$ Núcleos de vecinos, presidencias municipales, maestros estatales, maestros federales, agricultores aislados, asociaciones de mejoramiento local, gestaron una intensa correspondencia con la Secretaría de Gobernación federal interesados en ocupar temporalmente los espacios eclesiásticos clausurados.

${ }^{17} \mathrm{Al}$ menos 24 poblados de la zona de Texcoco reportan presencia de facciones adheridas al cisma católico liderado por el patriarca Pérez y su Iglesia Católica Apostólica Mexicana. Fondo Dirección General de Gobierno. Expedientes 2/342/12, 2/343/12 y 2/347/13. Archivo General de la Nación (AGN), México.

${ }^{18}$ Secretario general de la Liga a presidente de la república. Cuautzingo, 27 de febrero de 1926. Fondo Álvaro Obregón-Plutarco Elías Calles. Exp. 104-L-23. AgN, México.

${ }^{19}$ Dirección General de Gobierno. Caja 28, exp. 15. AGN, México.

\section{()(1) $(9$}


bían al presidente de la república los afiliados al Partido Agrarista del Estado de México (una tendencia del Partido Nacional Agrarista favorable a Luis N. Morones, personaje central en la política de Calles hacia la Iglesia): "Los Comités Agraristas de este pueblo y su barrio, por mayoría de los vecinos lo felicitamos calurosamente por viril actitud con los elementos clericales y reaccionarios." ${ }^{20}$

También se posicionaron en favor de la política federal los afiliados al credo protestante. Aunque su iglesia fue objeto del control legal, parece claro que sus integrantes coincidieron con el gobierno federal, que tendió históricamente a verlos con buenos ojos, en tanto lo ayudaban a debilitar las posiciones del Episcopado católico.

El involucramiento de los protestantes sale a relucir en algunos incidentes con la escuela rural federal. Entre los firmantes de la carta en defensa del plantel de Huexotla, antes citada, es posible reconocer la rúbrica de Luz Fermoso, por su peculiar apellido seguramente emparentada con el ministro evangélico Mariano Fermoso (director de la escuela metodista Benito Juárez, de Texcoco en 1909, ${ }^{21}$ encarcelado en 1931 por su presidente municipal por oficiar sin dar aviso) y con Pedro Fermoso, que por aquel entonces figuraba en algunas denuncias contra la autoridad municipal por abuso en asuntos relativos a la escuela. ${ }^{22}$

También hallamos entre los firmantes de la denuncia de reuniones sediciosas en El Atorón del Diablo a protestantes conspicuos como el pastor Abraham Ávila, director del instituto metodista de enseñanza primaria Hijos de Hidalgo, anexo a la fábrica de Miraflores, líder de una definida estrategia agrarista de colaboración con las políticas de Estado federal. Con epicentro en la peculiar comunidad de Miraflores (donde el metodismo se había implantado en 1874 asociado a la fábrica textil del inglés Robertson, alcanzando interesantes progresos en el impulso de nuevas instituciones culturales), el pastor Ávila ejerció un notable influjo cultural sobre los agraristas del distrito de Chalco, entre los que predicó el ideario metodista y a los que impulsó en sus movilizaciones por la tierra y por la escuela. En un interesante estudio sobre el metodismo en Miraflores, Laura Espejel (s. a.) señala:

${ }^{20}$ Comité Agrarista a presidente de la república. San Simón, 11 de agosto de 1926. Fondo Álvaro Obregón-Plutarco Elías Calles. Exp. 104-L-23. AgN, México.

${ }^{21}$ Noticia exámenes escuelas primarias distrito de Texcoco. Texcoco, 4 de enero de 1909. Fondo Escuelas Particulares. Vol. 2. Archivo Histórico del Estado de México (AHEM), Toluca.

${ }^{22}$ Fondo Dirección General de Gobierno. Caja 28, exp. 50. AGN, México.

\section{()(1) (}


El grupo agrarista del pastor Ávila se constituyó con base en los pueblos que pertenecían a la congregación. En sus mínimos apuntes biográficos, él habla de 33 pueblos que obtuvieron la dotación. El 7 de enero de 1927 los representantes de las agrupaciones agrarias de San Gregorio Cuautzingo, San Juan Atzacualoya, Tlapala, Temamatla y Tezoquipa-Miraflores le otorgan en una carta su reconocimiento y le delegan la representación para entrevistarse con el presidente de la república; los firmantes eran en su mayoría metodistas (pp. 20-28).

Los agraristas metodistas de San Gregorio Cuautzingo se convertirían en férreos defensores de la escuela rural federal de su pueblo, desde la que librarían una verdadera guerra faccional contra los defensores locales de la religión -los "fanáticos"- que se prolongó durante años hasta editar uno de los escasos "amotinamientos severos" que conocería en la región la escuela rural federal de 1923 a 1940. La SEP tenía amigos tanto en Cuautzingo como en la vecina colonia agraria de Tezoquipa (una de las gestiones emprendidas por Ávila, en donde eventualmente los ejidatarios tramitarían con la Secretaría el rescate del abandonado plantel del instituto Hijos de Hidalgo). También los tenía en Huexotla (donde hallamos a los Fermoso), Chicoloapan (a la maestra Membrillo) y Cocotitlán (profesor Giesseler). Amigas del plantel y de la política federal, las facciones agraristas con influjo protestante tomaron parte en las nuevas alianzas sociales mediante las que se consolidaba el Estado nacional posrevolucionario.

Liberales y masones igualmente hicieron pública su simpatía por la política federal. Presente en la misiva del señor Samuel Villa, que alertaba a Calles sobre la necesidad de instalar en los pueblos comisarios liberales como medio para lograr el efectivo control del clero, ${ }^{23}$ un liberalismo histórico emerge en otras adhesiones locales que recibe la política callista, como la del Partido Liberal "Sebastián Lerdo de Tejada", de Amecameca, la de los masones de Texcoco y las del Partido Liberal "Texcocano". ${ }^{24}$

${ }^{23}$ El denunciante apunta rasgos de la estructura política que apoyaba localmente al poder religioso: "Los comisarios de hoy, Jueces Auxiliares de la época pasada todos sin ecepción [sic] son mayordomos del santo patrón, Sacristanes, cantores [...] de la Iglesia”, por lo que suplicaba se pusiese cuidado "en poner en los pueblos Comisarios Liberales [...] busque liberales en los pueblos y póngalos de comisarios”. Samuel Villa a ministro de Gobernación. Texcoco, 15 de diciembre de 1926. Fondo Dirección General de Gobierno. Caja 28, exp. 14. AGN, México.

${ }^{24}$ Fondo Álvaro Obregón-Plutarco Elías Calles. Exp. 104-L-23. AgN, México.

\section{()(1) $\$$}




\section{La pugna por los espacios}

La suspensión del culto produjo rearticulaciones en la vida de los pueblos. No sólo fracturó sus vecindarios en asuntos públicos como la escuela, el templo o el ritual, haciendo aflorar (o atizando) nuevas (y viejas) escisiones faccionales ${ }^{25}$ a propósito del combate por la fe, sino que introdujo en muchos pueblos un perceptible proceso de recomposición del espacio público, cuyos emplazamientos centrales arribaron en la década de los treinta exhibiendo transformaciones que hicieron emerger escuelas, cárceles y mercados públicos a partir del antiguo espacio eclesiástico. ${ }^{26}$

En la nueva situación creada, maestros e inspectores de la SEP tornaron su mirada hacia los bien edificados espacios eclesiásticos disponibles, con la idea de establecer en ellos aulas, parcelas escolares, teatros al aire libre y demás dispositivos anexos al modelo de enseñanza federal. Un nuevo orden micropolítico emergió entonces en derredor de los templos, dándose un profuso proceso de pugna local en el que típicamente se alinearon, de un lado, los intereses de la escuela (y de las facciones que localmente se le aliaban: agraristas, liberales, protestantes, entre otros) y los de la Iglesia católica (en el que se alineaban: "fanáticos", autoridades locales, sociedades de culto, etcétera).

${ }^{25}$ Se impone insertar aquí un comentario al estudio de Alan Knight (2005) sobre las formas de mediación y representación local aparejadas por el proceso de formación del Estado federal posrevolucionario y al papel desempeñado por el caciquismo y el faccionalismo. Asumiendo el último como un fenómeno de orígenes difusos en la historia local (que reedita sus oposiciones fundacionales con cada nuevo asunto político del fluir histórico pueblerino), en el que se compenetran procesos asociados tanto al cacicazgo como a aspectos de clase, sangre, etnia, territorio y actitud ante la innovación, Knight propone una taxonomía de las distintas rationale (lógicas de acción) presentes en la emergencia de procesos de faccionalización. Lo que aquí recibe el trato de faccionalismo (la división del pueblo en términos de bandos en interacción conflictiva en torno a la escuela) tuvo rationales que resulta complejo analizar en términos de las expuestas por el autor. No era meramente un combate entre la innovación y el tradicionalismo el que configuraba, por ejemplo, la oposición entre católicos y protestantes. Tampoco traducían siempre, necesariamente, pugnas entre familias y linajes. A veces traducían constituciones subjetivas de clase, otras traslucían rivalidades entre pueblos. Sin embargo, eran más complejas y dinámicas, requiriéndose, definitivamente, hacer un esfuerzo por captarlas como relaciones inestables, establecidas en función del interés y las estrategias por el poder.

${ }^{26}$ Aunque, en lo que sigue, se analizará el papel desempeñado por el actor federal, debe decirse que también las autoridades locales expandieron su influencia al espacio clausurado de los templos, para establecer allí mercados públicos, lavaderos, aulas y prados. Algunas escuelas oficiales se alojaron temporalmente en edificios y atrios, permaneciendo allí a pesar de haberse resuelto el conflicto, como explicaba al presidente Ortiz Rubio el párroco de San Martín de las Pirámides. Marcial Sánchez a presidente de la república. San Martín de las Pirámides, 27 de agosto de 1920. Fondo Dirección General de Gobierno. Caja 20, exp. 37. AGN, México.

\section{(ㅇ)(1) $\$$}


Varias iniciativas por la apropiación de espacios eclesiásticos surgieron de parte de maestros, inspectores y Comités de Educación federales. Por ejemplo, el inspector Miguel A. Gómez, semanas antes de clausurar la escuela de Huexotla, intentó tramitar ante Bienes Nacionales la cesión de las casas curales del lugar y del vecino pueblo de San Bernardino "con el fin de hacer cesar de una vez los ataques de los miembros de la liga religiosa, quienes no dejan al pueblo se disponga de ellas para beneficiar a las escuelas federales establecidas en dichas poblaciones". ${ }^{27} \mathrm{O}$ las que, de modo similar, realizó en pos de la cesión de un lote de terreno del templo de Amecameca, para que sirviese de parcela a la escuela federal del barrio de San Juan.

En sus iniciativas, el inspector contó generalmente con el apoyo local de núcleos de vecinos. Los de San Pablito, por ejemplo, gestionaron directamente ante Bienes Nacionales la cesión de una franja de diez metros del antiguo cementerio, denunciando en ese mismo escrito el accionar de algunos vecinos que habían venido obstaculizando las labores de la escuela al empeñarse en preservarlo intacto. ${ }^{28}$ También lo apoyaron en 1926 los protestantes de Huexotla, con éxito más bien relativo, pues el plantel sufrió una clausura temporal y tuvo que devolver en 1930 los terrenos que empleaba para campo deportivo y teatro al aire libre, que "fueron suprimidos por encontrarse instalados en un anexo del templo". Y así sucedió en otros tantos pueblos.

Sin embargo, en la puja por los espacios eclesiásticos, las posiciones federales llevaron las de perder. La movilización de la facción católica logró contener muchas de sus iniciativas y puede decirse, en un balance somero, que los espacios conquistados durante los años de 1926 a 1929 tuvieron menor relevancia estratégica que las muchas escuelas desestabilizadas por la pugna religiosa, particularmente aquellas permanente o transitoriamente clausuradas.

\section{El bloque conservador local}

Localmente, el catolicismo desplegó distintas formas de resistencia a la expansión federal. Un incidente acaecido en el pueblo de Tepexpan en 1929 per-

${ }^{27}$ Inspector Miguel A. Gómez a director de Educación Federal. Texcoco, 30 de junio de 1926. Fondo Dirección de Educación Federal en el Estado de México. Caja 829, exp. sin clasificar. AHSEP, México.

${ }^{28}$ Juez Auxiliar de San Pablito a director de Bienes Nacionales. San Pablito, 23 de junio de 1927. Fondo Departamento de Escuelas Rurales. Expediente 4/11466. AHSEP, México.

\section{(이이 $(3$}


mitirá introducirnos en una de ellas: el rumor. Como la concurrencia escolar directa (creación de escuelas confesionales clandestinas), el rumor constituyó una forma de contención a la escuela federal durante la coyuntura religiosa. Al tiempo que los pueblos se llenaban de rumores sobre las intenciones pedagógicas del actor federal, una nueva oferta educativa -salvacionista y de carácter clandestino- emergió en ellos como mecanismo de contención de la política pedagógica de la Secretaría. Comentando el caso de Tepexpan, el inspector Carlos Mercado afirmaba:

Tuve que lamentar la poca asistencia que en relación con el Censo Escolar es perfectamente nula. Al preguntar la causa [...] los vecinos me informaron que existen en el lugar 3 colegios particulares que últimamente y valiéndose de la ausencia de profesores por asistencia a cursos de perfeccionamiento a Chalco, se habían apropiado los alumnos que asistían a la escuela rural. Que en el pueblo se ha esparcido la noticia de que el letrero "Esc. Rural Federal", está diciendo con toda claridad que en ese plantel se formarán soldados para mañana, posiblemente recordando equivocadamente a los antiguos rurales [...] como el fanatismo reinante en aquel lugar es el que más mala atmósfera le está creando a nuestra escuela, teniendo como arma poderosa un colegio particular católico [...] [que] cobra 25 centavos por alumno, asistiendo 80 de ambos sexos [...] La clase humilde del pueblo, el agrarismo y el capitán destacado manifestaron grandes deseos de ayudar a la escuela y todos los esfuerzos que se han llevado a cabo por lograr que se sostenga, pero el fanatismo por un lado y la clase acomodada por el otro han obstaculizado. ${ }^{29}$

"Rurales del mañana", "protestantes", "bolshevikis" y demás mitos nutrieron el rumoreo local, fincando actitudes de ruptura cultural con el plantel y sus actores. De accionar un tanto difuso, el rumor limitó el poder de convencimiento local de maestros e inspectores, produciéndole a la escuela federal un clima culturalmente esquivo. Desde el mismo 1923, en el debut de la Secretaría en la región, el clero católico hizo uso del púlpito para constituirla como un enemigo cultural de orden nebulosamente confesional. Decía entonces el misionero Ricardo Sánchez:

${ }^{29}$ Inspector Carlos Mercado a jefe de Departamento de Escuelas Rurales Primarias Foráneas y de Incorporación Cultural Indígena. Texcoco, 15 de junio de 1929. Fondo Departamento de Escuelas Rurales. Exp. 37/11801. AHSEP, México.

\section{(ㅇ)(1) $\$$}


el Clero de acuerdo con el Presidente Municipal (propietario este de una Iglesia), trabajaba activamente obstruccionando la labor de la SEP [...] [para] dar un mentís a la dolosa propaganda que en mi contra hacía el Clero [...] no encontraba el medio de sincerarme ante el pueblo que sólo veía en mí al protestante, al bolshevique y al [...] qué sé yo. Cuando los vecinos [...] vieron que... no se enseñaba culto religioso alguno ni se aconsejaba tal o cual credo político-social [...] irradió [...] la confianza. ${ }^{30}$

Más por "protestante" que por "bolsheviki", la propaganda eclesiástica contra el inspector creaba alarma respecto del retorno del protestantismo como enemigo regional históricamente testificado por los católicos. ${ }^{31}$ Así, en agosto de 1926, el inspector Gómez reportaba desde Acuéxcomac que la débil asistencia al plantel federal se debía a que "existe en el lugar una escuela particular católica, lo que impide mayor asistencia a la federal por haberla calificado de protestante". Para diciembre la escuela federal debió clausurarse por la competencia que le hacía el establecimiento particular. La clausura significó para la Secretaría de Educación Pública una derrota definitiva en el pueblo de Acuéxcomac, al que no volvería hasta después de 1940. Consumada en 1926, la derrota del plantel federal por la concurrencia cultural de la enseñanza particular confesional se había gestado tres años atrás. ${ }^{32}$

Es difícil precisar cuántas escuelas particulares surgieron coyunturalmente en los pueblos como parte de la ofensiva cultural de los creyentes católicos. En tanto fenómenos de coyuntura, esas escuelas brotaban como lo describía el inspector Sánchez: a instancias de un cura que delegaba en individuos esa misión salvacionista. En otros casos, surgían por iniciativa de

${ }^{30}$ Ricardo Sánchez a director de Educación y Cultura Indígena. Texcoco, 26 de julio de 1923. Fondo Departamento de Educación y Cultura Indígena. Exp. 706.5. AHSEP, México.

31 Es llamativo que la zona del Distrito de Chalco se halla visto casi exenta de la conflictiva confesional del periodo 1923-1929, reportando contados incidentes de agitación religiosa. ¿Tuvo que ver ello con las tradiciones liberales y protestantes que cobraron fuerza en sus pueblos desde el último cuarto del siglo XIX? ¿Tiene que ver la marcada concentración del Conflicto Religioso en los municipios de Texcoco durante los años veinte con la barrera histórica que parecieron representar sus comarcas a la expansión decimonónica del protestantismo?

32 En septiembre de 1923, el misionero Ricardo Sánchez había transmitido a su superior lo siguiente: "pero como a últimas fechas el cura de Tulantongo nombró a una mujer para que enseñe en Acuéxcomac la religión católica, varios de los alumnos de la citada señorita [la maestra federal] se pasaron a la escuela católica bajo la pena de excomunión con que amenazó el referido cura”. Ricardo Sánchez, misionero en Texcoco a Enrique Corona. Texcoco, 15 de septiembre de 1923. Fondo Departamento de Educación y Cultura Indígena. Exp. 706.5. AHSEP, México.

\section{()(1) $\$$}


maestros libres interesados en capitalizar laboralmente la reorientación de la demanda pedagógica local, o por iniciativa de actores como el que reportaba el inspector estatal Antonio Albarrán durante la visita que hizo al pueblo de San Bartolo, en 1927, intentando esclarecer una denuncia federal sobre la presencia de un plantel con inclinación religiosa:

La Escuela es pequeña en cuanto a su personal, pues sólo cuenta como Profesor con el C. Cipriano Aguilar, y con 25 niños inscriptos, de los que concurren por término medio 18. La Escuela fue fundada en 1925. Su fundador ha sido en otro tiempo Presidente Municipal de Acolman, y después, comisario de San Bartolo [...] En cuanto a la enseñanza de la religión, creo haber averiguado de un modo cierto [...] que desconociendo este la prescripción constitucional que prohíbe la enseñanza religiosa aun en las escuelas particulares, por ser muy raro que en algún pueblo haya siquiera un ejemplar de la Constitución Política [...] desconociendo esa prescripción, repito, daba algunas explicaciones sobre doctrina cristiana a principios del año próximo pasado [...] pero desde julio del aludido año 1926 [...] comprendió que aquella enseñanza no convenía ya en la escuela. ${ }^{33}$

Escondidas entre el caserío, ese tipo de escuelas no formaba parte de la red de planteles particulares de asociaciones religiosas originada en el porfiriato, que parcialmente subsistía en la región hacia mediados de los años veinte. ${ }^{34}$ Valga como ejemplo sincrónico (por su riqueza expresiva) el incidente narrado por el inspector federal Bartolo Gómez en el mes de julio de 1940, a finales del cardenismo:

me permito hacer del superior conocimiento [...] que en el Mpio. de Chimalhuacán, según los informes que me han estado proporcionando los maestros federales y estatales, funcionan varias escuelas particulares, clandestinamente, siendo la más importante la de la cabecera [...] atendida por unas señoritas, a quienes les dicen madres o monjitas y cuentan con el apoyo del cura del lugar y seguramente con el disimulo de las Autoridades Municipales. Difícil es localizar la Escuela porque cuando saben que se les busca cambian de local,

${ }^{33}$ Inspector Antonio Albarrán a director general de Educación Pública del Estado. Texcoco, 1 de mayo de 1927. Fondo Escuelas particulares. Ahem, Toluca.

${ }^{34}$ Cerca de 30 planteles confesionales gestaron católicos y protestantes en los distritos de Texcoco y Chalco durante el último cuarto del siglo xix.

\section{(ㅇ)(1) $(3$}


repartiéndose por grupos en varias casas [...] En Xochiaca [...] tienen Escuelas Particulares con alguna asistencia las señoritas Josefina y Guadalupe Buendía y Paz Ochoa, restándole alumnos a las escuelas que funcionan legalmente. ${ }^{35}$

Como puede notarse, en la versión federal la autoridad local figura siempre en alianza con el bloque opositor a la escuela. Verdaderamente desde abajo, una estructura de poder anidada en los cargos de representación político-administrativa (comisarios pueblerinos) es reiteradamente acusada de confrontar los deseos de implantación de las escuelas rurales. Comisarios que no ayudan, que interfieren bajo el mando de presidencias municipales en claro vínculo con el clero local. Presidencias que, a la hora de las denuncias federales, convalidan el actuar de esos comisarios, sosteniéndolos en tanto, miembros del séquito administrativo designado por ellos mismos en pueblos y barrios de su jurisdicción. Presidencias que no cumplen con su deber constitucional en materia religiosa. Burocracias estatales que, cuando averiguan hechos de boicot confesional a instancia del poder federal, nunca hallan y, cuando hallan, componen. ${ }^{36}$ Presidentes municipales, primeros y segundos comisarios pueblerinos, jueces de instancia, agentes del timbre y otros personajes del poder administrativo local constituyen un reparto estable en el elenco de personajes que cotidianamente "obstruccionan" la implantación federal.

La alianza conservadora entre autoridad política local y poder religioso en efecto pareció tomar enteramente cuerpo en la región de estudio. Su accionar aparenta no haber sido mera percepción maniquea de maestros, inspectores y directores de educación federal. Acervos de documentación como el de la Dirección General de Gobierno (del Archivo General de la Nación) confirman lecturas similares, producidas por grupos enfrascados en la pugna por asuntos distintos aunque no distantes de los de la escuela. Incluso

35 Inspector B. Gómez a director de Educación Federal. Chalco, 2 de julio de 1940. Fondo Escuelas particulares. Vol. 9. AHEM, Toluca.

${ }^{36}$ En el nivel local, el bloque conservador contó con el abrigo de presidencias municipales y burócratas del poder estatal central, cosa que puede afirmarse cuando se valora el resultado global a que condujeron las denuncias de boicot religioso cursadas por la SEP ante el gobierno estatal durante esos años. Puntualmente, el inspector estatal se hacía presente en el teatro de operaciones para encontrar - de modo, a veces, enteramente predecible- que nada de lo denunciado existía. Incluso, en relación con el caso de la controvertida escuela católica de la hacienda de Atoyac, en San Gregorio Cuautzingo, el secretario general de Gobierno del estado llegó a recomendar a su dueña, la señora viuda de Galarza, eludir la clausura del plantel cambiándole el nombre. Fondo Escuelas particulares. Vol. 5. Ahem, Toluca.

\section{()ㅜ(1) $\$$}


existen versiones de la propia administración política local que la denuncian desde dentro, como se verá a continuación.

En la posición de caso que confirma la regla, el presidente municipal de Atenco daba en 1923 esta interpretación al asunto de la violación del sello de clausura impuesto por él a la escuela particular de la señora Espinosa de Jolalpa que había denunciado el inspector federal en el pueblo de Acuéxcomac:

A raíz de establecidas en este Municipio algunas Escuelas Rurales por la Federación, el Cura Párroco de Tulantongo señor Aniceto Ramírez, valiéndose del púlpito propaló especies falsas contra las mismas [...] y de aquí que estableciera en el [...] pueblo la Escuela de que se trata para restar asistencia de niños a las Escuelas Federales [...] la señora de Jolalpa dice que ella [no] rompió el sello, lo que parece no ser verdad, porque el citado día 17 vinieron a su casa donde está el plantel los CC. Presidente Municipal de Texcoco, así como el Párroco Aniceto Ramírez, quien ha conseguido el apoyo de dichas autoridades para que no se cierre la Escuela [...] en concepto de esta oficina, el [...] plantel debe ser clausurado [...] me permito suplicar a Ud. se sirva [...] indicar al C. Presidente Municipal de Texcoco se abstenga de intervenir en asuntos que no son de su jurisdicción porque entre esta Presidencia y esa Superioridad no hay autoridad intermediaria. ${ }^{37}$

Expresos en el clamor por "comisarios liberales" que contrarrestasen la hegemonía del bloque conservador en los pueblos, los prolijos reportes de inteligencia que en esos mismos años hacen las facciones aliadas al cisma católico mexicano describen redes de "contubernio" político-religioso que se elevan desde los municipios hasta el centro político de la autoridad gubernativa estatal. ${ }^{38}$

El cisma conducido por el patriarca Pérez Budar agregó densidad al problema del faccionalismo local y los proyectos de institucionalización de la Escuela Rural Federal. Aunque su renacer durante la Cristiada (1927-1929)

${ }^{37}$ Presidente municipal de Atenco a secretario general del superior gobierno. Atenco, 20 de octubre de 1923. Fondo Escuelas particulares. Vol. 5. AHEM, Toluca.

${ }^{38}$ Denunciaban los cismáticos que, en un banquete clandestino celebrado en Tezoyuca, al que habían acudido jerarcas religiosos, ex presidentes municipales, Caballeros de Colón, Adoradores de Cristo ("y demás clase política"), se había proferido el siguiente aforismo: "Muerto Calles, preso Obregón, es momento propicio para ir contra los agraristas que tenían las tierras de la hacienda, arrebatadas contra un derecho divino." Trinidad Ramos y demás firmantes a secretario de Gobernación. Tezoyuca, 16 de enero de 1928. Fondo Dirección General de Gobierno. Caja 28, exp. 2. AGN, México.

\section{(ㅇ)(1) $\$$}


no era ya producto de la alianza con el callismo, como señala Mario Ramírez Rancaño (2006), a ojos del bloque católico los intereses de la Iglesia Católica Apostólica Mexicana y los de la Secretaría de Educación Pública concurrían en un mismo fin: el fortalecimiento del amenazante poder federal. ${ }^{39}$

Presentes en varios pueblos texcocanos desde los días iniciales de la cruzada federal por el control curricular (ca. marzo de 1926), el discurso y el accionar de los cismáticos tendió a posicionarlos en una suerte de alianza con la SEP. La apropiación de templos clausurados por los fieles seguidores de Pérez Budar, ${ }^{40}$ la denuncia de actividades clandestinas de los católicos romanos, fueron actos a través de los cuales las facciones cismáticas se colocaron objetivamente en alianza con la escuela federal, dando pie a la interpretación conservadora de que ambos procesos formaban parte de una ofensiva política común. ${ }^{41}$

Pesquisa en la que habría de profundizarse, existen, no obstante, testimonios como el de Manuel Muñoz y los 27 adheridos al cisma que comunicaban al secretario de Gobernación desde San Bartolo: "Que cumpliendo con las leyes de culto, las autoridades municipales dieron permiso para celebrar la fiesta titular del 28 de agosto [...] cuando el sacerdote de la Iglesia Mexicana se hallaba registrado debidamente ante el Presidente Municipal, el fiscal del templo, Cipriano Aguilar, se negó a entregar las llaves de la iglesia para la celebración de la fiesta." ${ }^{42}$

A continuación, los firmantes denunciaban que el fiscal del templo obedecía instrucciones de los Caballeros de Colón y que tenía un colegio católico en su domicilio, solicitando al secretario se le conminase a entregar las llaves del templo y a clausurar la escuela. Don Cipriano Aguilar, al que acabamos de ver alegando desconocimiento de la Constitución de la república

${ }^{39}$ El apasionante estudio de Mario Ramírez Rancaño sobre la Iglesia Católica Apostólica Mexicana muestra que el vínculo del cisma y los callistas desapareció tras los hechos de 1925, cuando fueron tomados los templos de La Soledad y Corpus Christi (México, D. F.) con el concurso de grupos obreros identificados con la CROM. Ramírez (2006) señala: "Cumplidos sus objetivos, lo altos personeros del régimen buscaron distanciarse de un movimiento religioso que ahora les resultaba incómodo. Ni Calles, ni Morones quisieron volver a acordarse de Pérez Budar, y la [...] (ском) no externó más declaraciones de apoyo” (p. 189).

${ }^{40}$ En el Estado de México, los cismáticos contaron con cerca de 25 templos; la región mexiquense del Valle de México fue territorio fundamental del cisma (Ramírez, 2006, p. 217).

${ }^{41}$ He detectado la participación de miembros de Comités de Educación federales en actividades cismáticas, hecho que también ha corroborado Miguel Lisbona en su estudio sobre la Iglesia católica mexicana en Chiapas (Lisbona, 2009, pp. 263-308).

${ }^{42}$ Manuel Muñoz a secretario de Gobernación. San Bartolo, Acolman, 25 de agosto de 1927. Fondo Dirección General de Gobierno. Caja 28, exp. 34. AGN, México.

\section{(ㅇ)(1) $\$$}


como norma práctica en su pequeña escuela, resulta, en esta otra faceta de la vida local, también enemigo de los cismáticos.

Así como los seguidores del cisma denunciaban la actividad educacional del bloque conservador, ${ }^{43}$ los leales a la Iglesia apostólica romana interpretaban el carácter de la entente que enfrentaban: la escuela federal y los seguidores de Pérez Budar. Creyéndolo de ese modo, los leales a la curia romana en Atenco pedían al secretario federal de Gobernación velar por que la correcta gestión de los templos no se viese entorpecida por la confabulación cismática de reclamarlos bajo su jurisdicción, agregando que:

podría suscitarse entre los vecinos [...] un conflicto cuya trascendencia no podemos prever, dado que se trata de algo muy hondo para el alma popular, cual es el ataque a su credo religioso [...] está demasiado arraigado en nuestro espíritu el respeto a nuestro antiguo, rito y es nuestro propósito, por ahora cuando menos, perseverar en él mientras la instrucción laica, eminentemente laica, que imparte actualmente el gobierno emanado de la Revolución produce sus efectos en la conciencia de nuestros hijos (cursivas mías). ${ }^{44}$

Estratégicos en el sentido de no revelar al secretario oposición a la escuela y a la pedagogía federal, los católicos de Atenco le hacían saber, sin embargo, que perseverarían en su lealtad a la Iglesia romana, al menos hasta que la acción de la educación "eminentemente laica" que impartían sus planteles operase una transformación en la conciencia de las generaciones jóvenes.

Así las cosas, muchos pueblos vivieron el fuego cruzado del combate entre esos bloques faccionales, que sumaban sus relaciones de fuerza a asuntos como la implantación del plantel federal en el marco del espacio religioso (templos, atrios y terrenos contiguos). En ocasiones, la reacción contra la escuela sobrevino por el intento tangible del actor federal por reclamar jurídicamente esos espacios, como en Huexotla y San Bernardino y otros pueblos, donde el plantel hubo de cerrarse, mostrando la absoluta hegemonía del bloque conservador. En otras, los equilibrios de fuerzas locales mantuvieron prolongadas guerras de posición en torno al espacio escolar. Un persistente litigio sobre la pretensión de la escuela por expandirse a costa del espacio

${ }^{43}$ Vecinos a secretario de Gobernación. Tepexpan, Acolman, 20 de agosto de 1926. Fondo Dirección General de Gobierno. Caja 28, exp. 12. AGn, México.

${ }^{44}$ Vecinos a secretario de Gobernación. Tepexpan, Acolman, 20 de agosto de 1926. Fondo Dirección General de Gobierno. Caja 28, exp. 24. AGn, México.

\section{(ㄷ)(1) $(3$}


eclesial la envolvió en pugnas por bardas, cementerios y mitos, como el que se produjo años más tarde en un pueblo situado en el distrito de Otumba, contiguo a Tepetlaoxtoc, en donde ocurrió lo siguiente: "En San Mateo Mozoquilpan, el sacerdote hizo creer que el Niño Dios había pasado sobre un terreno que se encuentra tras de la escuela y que había dejado huellas. Con este motivo los vecinos evitaron que se borrasen dichas huellas y al mismo tiempo no se pudo abrir una parte del local que sumamente cerrado evitaba la entrada de aire y luz a la escuela." ${ }^{45}$

En el caso de San Pablito, la contención de la escuela no precisó relatos míticos. Allí, la facción conservadora plantó una barrera de contención tangible, como decía un inspector federal al presidente municipal:

El prof. M. Medina y la J.[unta] de E.[ducación] de San Pablo se quejan a esta inspección de que, un grupo de vecinos [...] pretende construir una barda frente al atrio de la Iglesia, que en la antigüedad fue cementerio; al realizar dicha obra, perjudican grandemente a la escuela federal quitándole el lugar donde los niños tienen su recreo [...] Este grupo [...] sistemáticamente [...] se ha negado a ayudar a la escuela [...] en todos momentos tratan de hostilizarla ${ }^{46}$

Bardas y sucesos metafísicos pretendieron instituir espacios de cerco a la expansión federal, en la lógica del lenguaje defensivo: "por aquí no te entrometas". En otras ocasiones, la reacción conservadora se expresó ofensivamente, boicoteando o destruyendo la implantación escolar. Desde Chimalpa, el inspector Gómez decía: "También [...] existe un expediente contra individuos del lugar que nunca han cesado de hostilizar la Escuela Federal, teniendo autorización para demandar auxilio de tropas federales [...] como cuando trataron de destruir el gallinero porque este se construyó junto a la iglesia del lugar." 47

En síntesis, los días del primer enfrentamiento sostenido entre el Estado y la Iglesia católica representaron un periodo enormemente conflictivo

${ }^{45}$ Inspector Septimio Pérez Palacios a director de Educación Federal. Texcoco, 30 de septiembre de 1936. Fondo Dirección de Educación Federal en el Estado de México. Expediente 288.3. AHSEP, México.

${ }^{46}$ Junta de Educación de la escuela de San Pablo, Chiconcuac, a director de Bienes Nacionales. San Pablo, 23 de junio de 1927. Fondo Departamento de Escuelas Rurales. Exp. 4/11466. AHSEP, México.

${ }^{47}$ Inspector Miguel A. Gómez a jefe de Departamento de Escuelas Rurales. Texcoco, 10 de febrero de 1927. Fondo Dirección de Educación Federal. Exp. 6/11473. AHSEP, México.

\section{(ㅇ)(1) $\$$}


para los procesos de institucionalización de la escuela rural federal en la región, particularmente en las escuelas del rumbo de Texcoco.

\section{LA AMPLIACIÓN DE LA COYUNTURA RELIGIOSA EN EL NIVEL LOCAL, 1923-1933}

Aunque las tensiones se agudizaron durante los años 1926-1929 (lapso en que usualmente se fecha principio y fin del Conflicto Religioso), resulta claro que este se remonta a los días del primer contacto de la escuela federal con el territorio y la sociedad de la región de Texcoco y Chalco. Sentados sus rasgos genéricos en aquel entonces, la oposición católica se manifestó abierta y generalizadamente al declararse la suspensión del culto y dar inicio la guerra Cristera (1926-1929), trayendo para los planteles de la Secretaría días de baja asistencia escolar y de permanentes conflictos locales, que entorpecieron su labor llevándola al grado de retirar sus escuelas de varios pueblos.

A pesar de las alianzas locales que logró concitar -que convirtieron la escuela federal en objeto de disputa faccional al interior de los pueblos-el balance de la acción educacional de la SEP en el territorio bajo estudio arroja claros y oscuros.

No obstante las adversidades, en 1929 la Secretaría lograba sostenerse en la región, contando, incluso, con ocho planteles más que los que tenía en 1925. Algo positivo en lo general, si bien debió retirarse de varios pueblos de modo definitivo. Resuelto el conflicto en junio de 1929, la escuela rural federal entraba a los años treinta con un perfil regional aparentemente consistente, dispuesto a profundizar la labor por la higiene social y la modernización productiva que la había caracterizado hasta entonces.

Los acuerdos de cese de hostilidades y el restablecimiento del culto de 1929 trajeron un nuevo ciclo ascendente de asistencia a los planteles, que alcanzó sólo a restituir parcialmente los niveles previos al conflicto, pero que difícilmente logró, en muchos casos, equipararlos. Aunque la finalización del conflicto trajo años de calma relativa, en los que la escuela profundizó su perfil higienista y productivo (1930-1933), la nueva coyuntura político-pedagógica abierta por la reforma de 1934 que decretaba la educación socialista haría renacer con fuerza los procesos de conflicto vividos en esta etapa.

En las localidades, el ambiente político en relación con las escuelas, los maestros y los inspectores federales quedó relativamente dañado por el Conflicto Religioso. La reapertura de los templos al culto conllevó el que

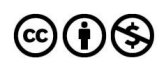


tuviesen que ser devueltos muchos de los espacios ocupados por la Secretaría durante su clausura, como en Huexotla, donde la escuela perdió, por ello, el campo deportivo y el teatro al aire libre que tenía establecidos en el atrio del templo. O como en Santiago Cuautlalpan, donde el párroco logró recuperar el área donde la escuela tenía sus anexos, generando diversas tensiones todavía en 1932. Como decía el inspector federal Pedro Moreno al reportar, en 1935, el estado de las escuelas de la zona de Texcoco: "los salones de clase que han sido construidos por los pueblos adolecen en su mayor parte de los siguientes defectos: están mal situados, en su mayor parte anexos a las casas curales, a las iglesias o a los cementerios y en el centro del poblado, asfixiándose la escuela por la aglomeración del vecindario." ${ }^{48}$ En esos espacios restados a la iglesia, la Secretaría comenzaría a sufrir distintas conflictivas después del restablecimiento del culto.

Un curioso documento firmado en nombre de la Unión de Sacerdotes Desocupados por un sacerdote apellidado Valdespino en septiembre de 1932, sitúa aspectos interesantes del clima sociocultural que rodeaba a la escuela rural federal. Dirigido al entonces secretario de Educación, Narciso Bassols, el escrito contiene una larga exposición sobre los problemas de la escuela rural y las vías para solucionarlos, con opiniones sostenidas por un núcleo de "humildes sacerdotes, que hemos vivido con las gentes humildes en los campos, convivido sus necesidades y conocemos de sobra su cultura e idiosincrasia". ${ }^{4}$

Centrado en la crítica al bajo salario docente, los excesivos programas de trabajo, la ausencia de una verdadera compulsión escolar y el fracaso en la laicización de la escuela, el escrito del sacerdote Valdespino describe lo que ocurría con la actitud de la gente hacia el maestro y la escuela federal tras el conflicto. Leamos los siguientes segmentos ilustrativos:

Aun cuando ustedes creen que a los maestros rurales, se les quiere mucho en el campo y se les adora, nosotros sacerdotes que hemos servido en comunidades donde los hay, sabemos de sobra que se les odia y más se les odió desde que el muy listo de Portes Gil, nos dio el permiso de volver a nuestras parroquias, pues antes, como faltábamos, el maestro hasta cierto punto, ocupaba nuestro lugar; pero volvimos y la educación rural sufrió su más aguda crisis, no sólo

${ }^{48}$ Inspector Pedro Moreno a director de Educación Federal. Texcoco, 15 de noviembre de 1935. Fondo Dirección de Educación Federal en el Estado de México. Exp. 201.5. AHSEP, México.

${ }^{49}$ Valdespino a secretario de Educación Pública. México, D. F., 9 de septiembre de 1932. Fondo Secretaría particular. Caja 5, exp. 26. AHSEP, México.

\section{(ㅇ)(1) $\$$}


porque nosotros nos presentamos en escena sino porque la gente, fanatizada ya de por sí, cree que nosotros le tiramos a la escuela y aunque esto no es cierto sin embargo los maestros de ustedes son mal vistos y mal tratados [...] [el maestro] compra todo más caro en las comunidades, porque sabemos bien que nuestros feligreses, en tratándose de maestros rurales, les venden todo más caro, si los huevos valen a cinco en el mercado al maestro se los dan a seis y así proporcionalmente todos los artículos de primera necesidad [...] A los maestros de ustedes no los ayuda ni el gobernador, ni el Presidente Municipal, ni los auxiliares, nadie. La gente del campo odia a la escuela y dejándola a su propia iniciativa, a su propia voluntad, a su propio albedrío ¿cuantos años se necesitará para que la educación de la generación actual sea un hecho? ${ }^{50}$

Puede admitirse prudentemente que la opinión del padre Valdespino valía, al menos, para caracterizar al segmento de fieles leales al clero romano en los pueblos. No es de admitirse, por ello, que el campesinado entero odiase a la escuela federal. Muchos pueblos siguieron mostrándole apego después de los acuerdos de modus vivendi de 1929, con el apoyo contingente de los mismos actores que la sostuvieron durante el conflicto: agraristas, protestantes, liberales y otros núcleos sociales que se adscribieron a las posiciones del Estado federal.

El interés de la versión radica en la alusión a un cierto clima inmediato al restablecimiento del culto, que deja percibir en los creyentes un cierto tono de desagravio ("y más se les odió desde que el muy listo de Portes Gil, nos dio el permiso de volver a nuestras parroquias, pues antes, como faltábamos, el maestro hasta cierto punto, ocupaba nuestro lugar; pero volvimos”). Justo por los días en que escribía Valdespino, en pueblos como Atlazalpan, Coatepec-Chalco y Cuautzingo, la pugna entre creyentes y agraristas subsistía, movilizándose las facciones en torno a la defensa (o la reconquista) de espacios y posiciones obtenidas (o perdidas) durante el conflicto. En Coatepec-Chalco, el asunto de la pretensión del inspector federal por retener tres hectáreas de tierra anexas al templo creó problemas durante todo el año de 1931. En San Pablo Atlazalpan y San Gregorio Cuautzingo se verificarían, en 1932, sendos plebiscitos en torno a la decisión sobre si la escuela rural federal debía instalarse en el pueblo. El plebiscito celebrado en el segundo pueblo significó una derrota para la inspección federal, ya que

${ }^{50}$ Sr. Valdespino a secretario de Educación Pública. México, D. F., 9 de septiembre de 1932. Fondo Secretaría particular. Exp. 26. AHSEP. México.

\section{(ㅇ)(1) $(2$}


su plantel no fue autorizado a establecerse, motivando un enfrentamiento abierto entre facciones agraristas y "fanáticas". Como el que preludiaban, en 1933, los reportes del inspector federal Ángel M. Corzo que veremos a continuación.

En un primer reporte, Corzo señala:

Desde el año pasado he estado pugnando por que en esta escuela se construya un nuevo salón; en el presente conseguí que se compraran los materiales necesarios que ya están dispuestos [...] les manifesté que si no se lleva a cabo esta construcción me veré en el caso de reducir el personal [...] porque no es posible que trabajen en el mismo salón [...] Este pueblo sufre una honda división religiosa que ha provocado desórdenes y aun crímenes, pero que poco a poco irán destruyéndose porque la escuela ha creado un núcleo importante de agraristas ejidatarios que la ayudan y desean que prospere. ${ }^{51}$

¿Era correcta la calificación de conflicto entre facciones religiosas? Aunque no hemos tomado conocimiento directo de congregaciones metodistas en San Gregorio Cuautzingo, lo cierto es que la cercanía del pastor Abraham Ávila prolongaba un contacto iniciado en el último cuarto del siglo XIX con la fundación de la congregación metodista del contiguo pueblo de Miraflores en 1874 por Guillermo Butler y sus hermanos de credo, los pastores Abundio Tovar, Guillermo Sherwell y Miguel Pinto. ${ }^{52}$

Inserta la escuela en esa presunta comunidad confesional, el bando contrario tendió a reaccionar, como lo señaló Corzo en otro reporte:

${ }^{51}$ Inspector A. M. Corzo. Informe. Texcoco, 27 de mayo de 1933. Fondo Dirección de Educación Federal. Caja 812, exp. 1588/11. AHSEP, México.

${ }^{52}$ En 1874, el fundador Guillermo Butler describió de esta manera la estrategia perseguida por la misión metodista en Miraflores: "El hermano Miguel Pinto ha entrado de lleno a nuestro servicio y va a salir en uno o dos días a Puebla y Cholula. Este es el hombre que servirá o será pionero en esos lugares. El hermano Pinto es de Chalco, pronto Ameca [meca] se nos abrirá. Pinto puede hacer ahí por nosotros... y se puede unir a Ameca con Cholula, completaría una línea de misiones que estarán unidas desde esta ciudad (México) a través de Miraflores hasta Puebla. Miraflores da al metodismo el control último del valle más histórico y fértil de México con su población agrícola" (citado en Espejel, s. a., pp. 10-21). Distante unos $9 \mathrm{~km}$ de Miraflores, el pueblo de San Gregorio Cuautzingo se hallaba a sólo cuatro de Tlapala, de donde era oriundo el general zapatista José Trinidad Ruiz, alumno del Instituto Hijos de Hidalgo y del Instituto Metodista de Puebla, dato significativo como muestra de la trama sociocultural que se trata de señalar.

\section{(ㅇ)(1) $\$$}


Como en un principio los católicos fanáticos le hicieron la guerra a la escuela al grado de que no querían que funcionara porque pensaban que iba a atacar sus creencias, les hice hincapié en lo significativo que resultaba la asistencia de tantos niños [...] La escuela ha hecho evolucionar a este pueblo que en un 18 de julio del año pasado se provocó un escándalo magno porque la Maestra pronunció un discurso exaltando la personalidad del Benemérito y alabando su obra. ${ }^{53}$

En otro encuentro con los vecinos, sostenido en el mes de agosto, Corzo había tratado el tema de:

los prejuicios que ciertos padres manifiestan porque la escuela no enseña religión, exhortándolos a que sigan ayudando [...] que se necesita con urgencia el nuevo salón que están construyendo. Me prometieron que pronto quedará terminado. Esta escuela solicitó que se ceda un pequeño sitio colindante con el patio y que pertenece a la Iglesia con objeto de establecer allí los anexos. ${ }^{54}$

Ya bastante tensos hacia 1933 los asuntos del faccionalismo religioso en San Gregorio (que seis años atrás habían medido fuerzas durante los espionajes en El Atorón del Diablo y la denuncia del plantel católico sostenido por la viuda de Galarza en la ex hacienda de Atoyac), la solicitud de una porción del atrio del templo para la escuela federal constituyó la gota que derramó el vaso. Dos años más tarde, en plena cruzada por la Escuela Socialista, el enfrentamiento faccional alcanzaría el carácter de severo y conduciría a la destrucción del plantel, que fue incendiado en un amotinamiento en 1935.

Así, reanudando el curso que introdujo el escrito del padre Valdespino, la coyuntura religiosa del callismo no terminó para la escuela rural con los acuerdos cupulares de 1929. Ni terminó para la escuela ni para las facciones cismáticas, que continuarían pulsando con los católicos romanos los templos y la vida pública en muchas de sus localidades. El retorno de los sacerdotes a los pueblos -que en enero de 1931 rebasaban el número

${ }^{53}$ Inspector A. M. Corzo. Informe. Texcoco, 15 de junio de 1933. Fondo Dirección de Educación Federal. Caja 812, exp. 1588/11. AhSEP, México.

${ }^{54}$ Inspector A. M. Corzo. Informe. Texcoco, 28 de agosto de 1933. Fondo Dirección de Educación Federal. Caja 812, exp. 1588/11. AhSEP, México.

\section{(ㅇ)(1) $(3$}


establecido para los distritos en $1926-{ }^{55}$ rearticulaba, en una suerte de problemático preludio, el camino de la nueva coyuntura que se abriría meses más tarde con la puesta en marcha de la reforma al artículo $3^{\circ}$ decretando la enseñanza socialista.

\section{CONCLUSIÓN}

Captada la escolarización en el nivel de las localidades, la noción del Conflicto Religioso como una "coyuntura" fechada entre 1926 y 1929 pierde sentido por cuanto, como se ha visto, el conflicto entre la ideología y la fe quedó planteado desde el momento en que la escuela rural federal arribó a las comarcas de nuestra región en la primavera de 1923. A la hora de la Ley Calles, de 1926, la tensión local entre el poder federal y el clero acumulaba tres años de pugnas, cosa que obliga correr hacia atrás nuestro criterio de periodización. Igualmente, debe movérselo hacia adelante dado que tampoco el modus vivendi de 1929 pareció poner fin al conflicto local entre la grey católica, sus intelectuales y la escuela federal.

Así, la certeza sobre una historia de continuo conflicto religioso con la escuela federal desde los primeros años veinte hace tambalear las nociones que tienden a situarlo como proceso de coyuntura fundamentalmente inscrito en el trienio 1926-1929, invitándonos a abrir retrospectivamente nuestra medición del tiempo histórico. En ese rasgo central de la institucionalización escolar federal, la coyuntura religiosa se revela como un proceso más antiguo. Y también más prolongado, como lo revelan estudios como el de Benjamin Smith (2004) sobre la política seguida hacia la escuela federal por el cuerpo clerical de la diócesis de Huajuapam, Oaxaca, entre 1930 y 1950, donde vemos reeditadas dinámicas de continuidad similares. Centrado en recuperar el nivel local de la dinámica del enfrentamiento escuela-credo, el trabajo de Smith prolonga el escenario del conflicto hasta bien entrada la década de los cuarenta, territorio en el que no hemos incursionado más allá de esa fecha mitológica de presunto cierre de coyuntura con el fin del régimen cardenista.

55 El decreto de 1926 establecía un máximo de 24 sacerdotes para ambos distritos. En enero de 1931 residían y oficiaban 32, esto es, 30\% más de los permitidos. Véase Secretario general de Gobierno a secretario de Gobernación. Toluca, 30 de enero de 1931. Fondo Dirección General de Gobierno. Caja 20, distintos expedientes. AGN, México.

\section{(이요 $\$$}




\section{LISTA RE REFERENCIAS}

Alfonseca Giner de los Ríos, J. (2011). Estructura y coyuntura. Política, cultura y micropolítica en la institucionalización de la Escuela Rural Federal en los Distritos de Texcoco y Chalco, 1922-1940. (Tesis de doctorado inédita). UnAM, México.

Blancarte, R. (1993). Historia de la Iglesia en México, 1929-1982. México: FCE.

Butler, M. (2002). Cristeros y agraristas en Jalisco: una nueva aportación a la historiografía cristera. Historia Mexicana, LII(2), 493-530.

Castro, D. (2003). La construcción de la laicidad en el sur del Estado de México. En M. Hernández y E. Juárez, Religión y cultura: crisol de transformaciones (pp. 181200). Zamora: El Colegio de Michoacán/Conacyt.

Espejel, L. (s. a.). El metodismo en Miraflores, Estado de México. Una experiencia local (1874-1929) [manuscrito inédito]. México: Dirección de Estudios Históricos-INAH.

Guerra, E. (2007). La salvación de las almas. Estado e Iglesia en la pugna por las masas, 1920-1940. Argumentos, xx(55), 121-153.

Knight, A. (2005). Caciquismo in Twentieth-Century Mexico. En A. Knight y W. Pansters (eds.), Caciquismo in Twentieth-Century Mexico (pp. 1-50). Londres: Institute for the Study of the Americas.

Lisbona, M. (2009). La Iglesia Católica Apostólica Mexicana en Chiapas (1925-1934). Relaciones, $\mathrm{xxx}(117), 263-308$.

Loyo, E. (1999). Gobiernos revolucionarios y educación popular en México, 1911-1928. México: Colmex.

Meyer, J. (1993). La cristiada (3 vols.). México: Siglo XXI Editores.

Meyer, J. (2007). Resistencias católicas en el México revolucionario a la hora del conflicto religioso. Recuperado de http://jg.socialsciences.manchester.ac.uk/docs/

Meyer, J. (2008). La cruzada por México. Los católicos de Estados Unidos y la cuestión religiosa en México. México: Tusquets/Océano.

Mutolo, A. (2005). El Episcopado mexicano durante el conflicto religioso en México de 1926-1929. Cuicuilco, XII(35), 117-136.

Olivera, A. (1987). Aspectos del conflicto religioso de 1926-1929. México: Secretaría de Educación Pública.

Ramírez, M. (2006). El Patriarca Pérez: la Iglesia católica apostólica mexicana. México: IIS-UNAM.

Smith, B. (2004). Religion, Politics and Education in the diocese of Huajuapam, Oaxaca, 1930-1950. Paper delivered at the 2004 Meeting of the Latin American Studies Association, Las Vegas, United States of America.

Torres-Septién, V. (1997). La educación privada en México, 1903-1976. México: Colmex/ Universidad Iberoamericana.

\section{()ㅜ(1) $\$$}


Valenzuela, G. (1998). La campaña presidencial de 1923-1924 en México. México: INEHRM. Yankelevich, P. (1997). La batalla por el dominio de las conciencias: la experiencia de la educación socialista en Jalisco, 1934-1940. En S. Quintanilla y M. K. Vaughan (eds.), Escuela y sociedad en el periodo cardenista (pp. 111-140). México: FCE.

\section{OTRAS FUENTES}

AGN Archivo General de la Nación, México.

AHSEP Archivo Histórico de la Secretaría de Educación Pública, México.

AHem Archivo Histórico del Estado de México, Toluca. 